International Journal of English Language and Literature Studies

$\operatorname{ISSN}(e): \quad 2306-0646$

$\operatorname{ISSN}(p): \quad 2306-9910$

DOI: $10.18488 /$ journal.23.2020.93.210.218

Vol. 9, No. 3, 210-218.

(C) 2020 AESS Publications. All Rights Reserved.

URL: wwrw.aessweb.com

check for
updates

\title{
STUDENTS' ATTITUDES TOWARDS WRITTEN ERROR CORRECTIONS: A STUDY IN AN OMANI EFL CONTEXT
}

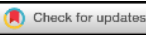

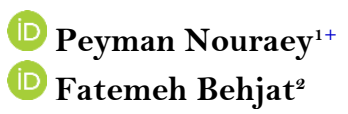

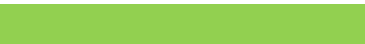

Article History

Received: 6 April 2020 Revised: 14 May 2020 Accepted: 18 June 2020 Published: 7 July 2020

Keywords

EFL learning mechanisms Encoding skills

Error correction

Feedback

General foundation program

Omani students

Written corrective Feedback

Written errors.

\author{
'Research Department, Gulf College, Muscat, Oman. \\ Email:peyman@gulfcollege.edu.om Tel:+96897903254 \\ ${ }^{2}$ Department of English Language, Abadeh Branch, Islamic Azad University, Abadeh, \\ Iran. \\ Email:Fb_304@yahoo.com Tel:+989173133393
}

\section{ABSTRACT}

Knowing errors and their sources often aids teachers in error correction processes. The present study aimed at investigating how the students of General Foundation Program (GFP) in Oman tend to deal with written error corrections and the related feedback provided to them. It is also an attempt to examine students' attitudes and preferences towards the feedback on their written errors. In doing so, sixty undergraduate students were selected as participants of the study. A questionnaire was distributed among the participants, containing information on a) when the students would prefer to receive the feedback on their written errors, b) who they would prefer to give the feedback, and c) what type of feedback they would prefer to receive. Findings revealed that the participants would mostly prefer to receive feedback on their written errors during the revising stage. In addition, it was highlighted that feedback provided by the teachers was more popular among the participants as compared to peer or self-corrections. Finally, results indicated that most of the students would prefer to receive feedback on all of their written errors, rather than some or none of the errors.

Contribution/ Originality: This study is first of its kind in the Omani context which focuses on the students' preferences towards written error corrections. It investigates students' attitude and when, how, and to what extent they would prefer to receive feedback on their written errors.

\section{INTRODUCTION}

Teaching English as a Foreign Language (TEFL) has mostly been regarded as a challenging area of Applied Linguistics. This is due to the nature of TEFL, which holds a significant deal of complex and inter-related processes (Guasti, 2017). In other words, language learning does not solely deal with the concept of language; it rather deals with several cognitive, psychological, cultural and many other processes which may directly or indirectly affect the learning output (Kramsch \& Widdowson, 1998). TEFL has also been diversifying based on various needs of people in different communities such as those related to economic, social, and technological communication at a global level (McDonough, Shaw, \& Masuhara, 2013). As such, English teachers may be engaged in English as a Foreign Language (EFL), English for Young Learners (EYL), English as a Second Language (ESL), English for Specific Purposes (ESP), and other similar areas (McDonough et al., 2013).

General English, being one of the mediums of TEFL, is widely taught at educational institutions of the world. It mainly consists of four skills (i.e., Writing, Speaking, Listening and Reading). As opposed to Reading and Listening, which are decoding skills, Writing and Speaking are considered as encoding skills in which the learner is 
supposed to create a set of codes for the reader or the hearer of a written or an oral text, respectively (Brown, 2000). In these encoding skills, which almost cover half of the learning process in both academic and non-academic contexts, learners are exposed to errors. These errors might belong to different sources such as psychological, physical and phonological sources, to name but a few. Accordingly, a significant and challenging phenomenon closely associated with such errors is the correction process and the feedback provided to students.

The issue of Written Corrective Feedback (WCF) has long been investigated among the researchers in the field. However, the effectiveness of WCF has remained a debating issue. A search into the literature indicates no agreement among the researchers and scholars as to what type, amount, and way of providing feedback to students shall be followed (Benson \& DeKeyser, 2019). To date, several studies have been conducted to investigate these issues (e.g., (Bijami, Pandian, \& Singh, 2016; Djumingin \& Weda, 2019; Eva, McMorrow, Molloy, \& Wilson, 2018; Lee, 2017; Mikulski, Elola, Padial, \& Berry, 2019; Mishchenko, 2019; Yang, 2019; Zhong, Yan, \& Zou, 2019)). However, this topic needs to be constantly researched, as contradictory results have been reported in terms of the effectiveness of WCF.

The importance of these encoding skills (i.e., Speaking and Writing) is known to almost every individual who is dealing with an academic setting. However, it seems that students get a higher chance of speaking rather than writing. For instance, in an EFL classroom, students generally interact through the medium of speaking and only start dealing with writing tasks when they are asked to do so. Therefore, it seems that the Writing skill is somehow neglected, paid less attention to, and needs to be studied more in various perspectives.

In line with this significance, the present study aimed at investigating how the students of General Foundation Program (GFP) in Oman tend to deal with written error corrections and the related feedback provided to them. To this end, we focused on the preferences of GFP students towards their written error feedback process in three different dimensions. These included: a) during which stage of writing they would prefer to receive the feedback b) who they would prefer to provide the feedback to, and c) what extent the feedback in question would suffice.

\section{LITERATURE REVIEW}

\subsection{Theoretical Considerations}

Knowing the nature of errors as well as their sources may aid the teachers in the correction processes. To date, several classifications of errors have been put forward by researchers and scholars. According to Riazi and Riasati (2007) there are mainly three types of error correction in an EFL context including a) teacher correction, b) selfcorrection, and c) peer correction. Selinker (1972) presented a taxonomy, conceptualizing five sources of errors with special reference to translated texts, namely, a) transfer of training, b) language transfer, c) strategies of second language communication, d) strategies of second language learning and e) overgeneralization of the linguistic material.

A quick search into the literature revealed that the primary causes of errors have been divided into three categories. These included:

a) Intra-lingual/developmental errors attributed to the language being learned, inadequate of the native language (Dulay \& Burt, 1974).

b) Inter-lingual/transfer errors attributed to the native language where the learners' first language habits prevent them from acquiring the rules and patterns of the second language (Corder, 1967).

c) Interference errors (or negative transfer) resulting from the negative influence of the mother tongue on the performance of the target language learners (Lado, 1964).

As Richards (1974) has pointed out, occurrence of errors is an essential part of any learning process. Davies and Pearse (2002) added that errors are among inevitable segments of this complicated process which might be tackled in different ways. As Kırkgöz (2010) argued, errors and mistakes are often used interchangeably; however, there are basic differences among these terms. According to Brown (2000), an error would refer to a deviant structure from the standard language which manifests the inter-language ability of the learner. 
Within an EFL context, two types of errors have been distinguished by scholars and theorists (e.g., (Brown, 2000; Cohen, 1991; Richards, 1974)). The first type of errors is related to the behaviorist school of thought. In this regard, teachers and learners are asked to avoid error occurrences as much as possible, so that the probable outcome would be a perfect language teaching (Brown, 2000). According to this school of thought, consistent exposure of learners to errors would gradually turn into a habit for them, and therefore, it would show a sign of inadequacy of teaching methods (Kırkgöz, 2010). The second school of thought, i.e., the cognitivist school, argued that whatever efforts made by the teachers in an EFL context, errors would eventually occur and this would not necessarily mean the learner's failure, rather a progress the learner is making in the language learning system (Kırkgöz, 2010).

Mistakes, however, are defined by Richards (1974) as a type of performance error which in turn would result in the learner using the language incorrectly. In fact, mistakes are errors which have often become a main part of learners' knowledge. Therefore, correction of errors in an EFL context seems to be of utmost importance before they turn into systematic mistakes.

A search into the literature revealed several tools related to feedback observation of students as well as teachers. One of the most common questionnaires in taking the students' feedback in an EFL context is the English Speaking Attitude Questionnaire (ESAQ). This has been utilized in various studies (Bui \& Intaraprasert, 2013; Canceran \& Malenab-Temporal, 2018). The Examinees Feedback Questionnaire has also been used for quite a long time to collect the feedback of teachers in an EFL context Nevo and Sfez (1985).

\subsection{Empirical Background}

The question of WCF, its effectiveness and efficiency have been among debating issues in the realm of second language (L2) teaching and learning. In other words, the effectiveness of providing feedback to students, the amount as well as the types of the feedback have remained controversial and are therefore doubted among the researchers and scholars. In this regard, Benson \& DeKeyser (2019) examined 151 essays of ESL students in search for the potential roles of direct vs. metalinguistic WCF, targeting simple past and present perfect tenses used by students. The participants were divided into three groups, two of which received explicit feedback, while the control group received general comments, only. Then, each of the groups was asked to write new essays based on the WCF provided. Findings of the study revealed that both treatment groups performed better in terms of their essay writings as compared to the control group which received general comments. This could in turn highlight the significant role of WCF in improving the students' writing skill.

Automated Written Corrective Feedback (AWCF) is a notion linked to WCF, where the feedback is provided automatically in a generic manner. An empirical study on AWCFs was carried out by Ranalli, (2018), in which, 82 ESL students participated. Their participations were in two sequenced developmental writing courses. Findings of the study indicated that generic feedback would lead into fewer successful error corrections than specific feedback. In addition, mental efforts were observed to be higher, while ratings of helpfulness and clarity were found to be lower in terms of generic feedback. According to Ranalli, (2018), in most of his analyses, the course level was not observed to be a significant factor.

With the advancement of knowledge and technology, online grammar checkers have gained a lot of popularity among students, as well as those who deal with a foreign language writing task. In line with this popularity, John \& Woll (2020) conducted an empirical study on two well-known online grammar checkers, namely Grammarly and Virtual Writing Tutor, as well as the Microsoft Word grammar checking function. In doing so, a wide range of grammatical error types from both authentic ESL compositions and a series of simple sentences generated by the authors were investigated. The outputs of these grammar checkers were then reviewed in terms of a) the number of corrections, b) the number of replacement suggested, and c) the number of false/inappropriate alarms. Findings of John and Woll (2020) indicated that the two online grammar checkers outperformed the Microsoft Word in a 
number of certain error types, although a higher number of corrections were provided by the latter. In addition, it was argued that these grammar checkers were not to be trusted in providing WCF to students.

Hibbert and Foncha (2019) carried out a study on communication skills as well as academic writing and reading skills of students in South Africa. Through a narrative design, participants were asked to write about their classroom learning experiences in addition to a needs analysis report. Based on the findings, defamiliarization was found to be an effective method which enhanced the participants' abilities in reading and responding to texts in addition to building self-confidence in their information synthesis ability. The study concluded that the problemsolving techniques of students could be developed through a community of inquiry framework.

While dealing with essays, students tend to make several mistakes. Nouraey, Cuarteros, and Khemiri (2016) conducted a study on Omani undergraduate students' essays to examine errors and mistakes. The study included fifty writing final examination papers from five different educational levels. Errors were categorized based on the taxonomy developed by Sattayatham and Ratanapinyowong (2008). A chi-square test was then used, the result of which revealed statistically significant differences among the frequencies of the students' error types and categories. The researchers provided detailed explanations on the nature of each error, as well as suggestions to tackle each error type. Eftekhar and Nouraey (2013) conducted a study to investigate the nature of English translations of Iranian product labels. In so doing, three-hundred translated labels of home appliances were collected through purposive sampling and then analyzed. The researchers utilized a model of error analysis conceptualized by Keshavarz (1992) consisting of three categories of errors namely, a) grammatical errors, b) semantic errors and c) pragmatic errors. Findings revealed that over half of the labels were erroneous, with grammatical errors being the most frequent one (i.e., 50\% of total errors). Hamouda (2011) aimed at investigating the EFL students' and teachers' attitudes and preferences towards written error corrections in the context of Saudi Arabia. The other focus of Hamouda (2011) was on the difficulties faced by both students and teachers within the feedback processes. Findings of the study revealed positive attitudes of the participants on written error feedback. However, significant discrepancies on how the errors had to be corrected were reported among the participants. As an example, students would opt for an overall correction, whereas most teachers would not. In addition, it was highlighted that students would mainly prefer teachers' corrections rather than those done by peer and/or self-corrections. Finally, some difficulties among the participants were reported and suggestions were provided.

The nature and effects of error feedback in second language writing classes were investigated by Ferris (2006). The study reviewed the written errors of 92 ESL students, where several errors were extracted out of them. The study reported a strong relationship among teachers' error markings and successful student revisions on their essay drafts. In addition, findings showed that most of the errors marked by the teachers were addressed by the students. Ferris (2006) also reported that both direct and indirect feedback strategies were addressed successfully in the students' revisions. This, in turn, highlighted the significance of feedback and correction.

\subsection{Research Questions}

In line with the objectives of the present study, the following research questions were posed:

1. When would the students generally prefer to receive feedback on their written errors?

2. Who would the participants prefer to provide feedback?

3. How much of the errors would the participants prefer to be corrected?

\section{METHODOLOGY}

\subsection{Participants}

Sixty students (thirty males and thirty females) participated in this study. The participants were selected based on accidental sampling from those studying General Foundation Program (GFP) in Oman. All participants were 
full-time students aged between 18 and 21, studying their first semester of GFP and their proficiency levels were determined by a standard placement test prior to course enrollment.

\subsection{Instrument}

A questionnaire was used in order to collect the data. This questionnaire aimed at collecting information on the students' attitudes towards written error corrections. It was adopted from a study carried out by Hamouda (2011) showing a relatively high level of reliability. In this questionnaire, several different aspects related to students' attitudes towards the problem of the study were investigated. The questionnaire included ten items which aimed at delving into the following issues:

- Students' preferences on when to receive feedback (i.e., at the pre-writing stage, at the drafting stage, at the revising stage, or at the evaluation stage).

- Students' preferences on who to receive the feedback from (i.e., the teachers, the peers, or self-correction)

- The amount of corrections made (i.e., all errors, some errors, or no corrections at all).

Students were given fifteen minutes of time to answer the questions. The questionnaire was translated into Arabic, as all students were native Arab speakers (some other nationalities rather than Omani students participated in this study, yet their native language was Arabic in all cases). This was to minimize the role of any interfering barrier in data collection (Cohen., Manion, \& Morrison, 2011).

\subsection{Data Collection Procedures}

The questionnaire was distributed among the participants during the second semester of the academic year 2018-2019. The participants were given half an hour to deal with the questionnaire. For each question, there were choices and participants were asked to choose the item which best represented their opinions. After collecting the questionnaires, the data were recorded and further analyzed.

\subsection{Data Analysis}

Results were demonstrated through calculation of the frequency and percentage of each response. In search for statistically significant differences among the frequencies of students' responses, the chi-square procedure was applied. All statistical procedures were carried out using SPSS software (v.25).

\section{RESULTS AND DISCUSSION}

Table 1 demonstrates the findings under each question and their relative frequencies:

Table-1. Frequency and percentage of responses by the participants.

\begin{tabular}{l|l|c|r}
\hline Item & Sub-Item & $\boldsymbol{f}$ of Responses & Percent \\
\hline \multirow{4}{*}{ Students preference on when to give feedback } & Pre-Writing Stage & 3 & 5 \\
\cline { 2 - 4 } & Drafting Stage & 21 & 35 \\
\cline { 2 - 4 } & Revising Stage & 24 & 40 \\
\cline { 2 - 4 } & Evaluation Stage & 12 & 20 \\
\hline \multirow{2}{*}{ Students preference on who to do the corrections } & Teachers & 39 & 65 \\
\cline { 2 - 4 } & Peers & 6 & 70 \\
\cline { 2 - 4 } The amount of corrections made by the instructors & Self-Correction & 42 & 20 \\
\cline { 2 - 4 } & All Errors & 12 & 10 \\
\cline { 2 - 4 } & Some Errors & 6 & \\
\cline { 2 - 4 } & All Corrections at & & 25 \\
\hline
\end{tabular}

Regarding the students' preferences on when to give the feedback, most of the participants agreed that the revising stage would be the most proper time $(f=24 / 40 \%)$. This was the stage during which the students were 
about to proceed to the final write-up, just after the drafting stage. In addition, the finding indicated that the drafting stage also seemed to be appropriate for the students to get feedback $(f=21 / 35 \%)$. The evaluation and prewriting stages ( $\mathrm{f}=12 / 20 \%$ and $3 / 5 \%$ respectively) were the least popular stages for the students to receive feedback on their writing tasks.

Most of the students would prefer to receive feedback from their teachers $(f=23 / 39 \%)$. Some of the participants believed that peers could also give proper feedback to them regarding their writing tasks and errors $(f=15 / 25 \%)$. The least appropriate correction belonged to self-correction by the students $(f=6 / 10 \%)$.

In addition, most of the participants $(f=42 / 70 \%)$ agreed that it would be better to receive feedback on all of their written errors. The other students believed that correction on some errors would suffice $(f=12 / 20 \%)$. Finally, a few students $(f=6 / 10 \%)$ argued they would not need any corrections on their written errors at all.

In search for statistically significant differences among the frequencies of the responses provided by the participants, a chi-square test was applied. The results of this test are shown in Table 2.

Table-2. Chi-square test on the participants' responses.

\begin{tabular}{|c|c|c|c|c|}
\hline Item & Sub-Item & Chi-Square & df. & $p$ \\
\hline \multirow{4}{*}{ Students Preference on When to Give Feedback } & Pre-Writing Stage & \multirow{4}{*}{18.000} & \multirow{4}{*}{3} & \multirow{4}{*}{0.0004} \\
\hline & Drafting Stage & & & \\
\hline & Revising Stage & & & \\
\hline & Evaluation Stage & & & \\
\hline \multirow{3}{*}{ Students Preference on Who to Do the Corrections } & Teachers & \multirow{3}{*}{29.100} & \multirow{3}{*}{2} & \multirow{3}{*}{0.0001} \\
\hline & Peers & & & \\
\hline & Self-Correction & & & \\
\hline \multirow{3}{*}{ The Amount of Corrections Made by the Instructors } & All Errors & \multirow{3}{*}{37.200} & \multirow{3}{*}{2} & \multirow{3}{*}{0.0001} \\
\hline & Some Errors & & & \\
\hline & No Corrections at All & & & \\
\hline
\end{tabular}

Results of the chi-square test revealed statistically significant differences among the frequencies of responses to each sub-item $(p<0.05$ for all three categories, as shown in Table 2.

Findings of the present work supported the results of Ferris (2006). In fact, Ferris (2006) highlighted the significance of feedback and correction on the errors of students with special reference to writing skill. It was reported that various strategies were utilized by the students and both direct and indirect feedback strategies were found to be useful for the students, as nearly all corrections were reported to be addressed by the students (Ferris, 2006).

The questionnaire used in the present work was based on Hamouda (2011) study. This questionnaire was similar to the framework conceptualized by Riazi and Riasati (2007). In both error correction taxonomies, three types of feedback were distinguished. These included a) teacher's feedback, b) self-feedback and c) peer feedback. Findings of the present work supported the results of Hamouda (2011) in two different ways. First, in both studies, the participants preferred teachers' feedback over the other two feedback categories. Second, the participants preferred an overall correction, rather than partial or no corrections at all.

Investigating several different aspects related to the four main skills in language learning has always been an area of interest to many linguists, researchers and scholars. Accordingly, the findings of the present study could have a significant impact on the optimization of one of the skills in question, namely, the Writing Skill. In other words, through putting the findings of the present work into consideration, the learners and teachers would be acquainted with the most frequent writing error correction tendencies in Oman. Several researchers have already tried to investigate the issue of written error correction and its related feedback (e.g., Chiang, 2004; Diab, 2005; Ferris, 2006; Ferris., 2003; Green \& Oxford, 1995)). However, based on the literature, the Omani EFL context has not been much investigated for this particular issue. The use of error analysis and appropriate corrective techniques 
may aid in the effective learning of English (Kern, 2000). This, in turn, would be helpful in improving Omani EFL contexts, both for the students as well as for the teachers.

\section{CONCLUSION}

The present work aimed at reviewing the students' attitudes, responses and preferences towards the written error corrections in an Omani EFL context. Findings revealed that the revising stage was the most popular stage to receive feedback on written errors among the participants. This would possibly show the preference of the participants to revise their written tasks before actually doing them.

In addition, it was highlighted that students would prefer to receive the feedback from their teachers, rather than peer and/or self-corrections. Previous studies have highlighted that peer-correction would sometimes affect the student's behavioral traits (e.g., self-confidence), as well as their trust in their peers in case of wrong or inappropriate corrections (Nouraey et al., 2016).

Finding also revealed that most of the students would prefer to receive feedback on all their written errors. All in all, findings of the present work would possibly shed light upon the students' written errors and how they would opt for corrections. The findings might be useful to teachers, students and researchers in the field of EFL. However, as stated earlier, a lot more needs to be done in terms of WCF and its effectiveness among the students.

Funding: This study received no specific financial support.

Competing Interests: The authors declare that they have no competing interests.

Acknowledgement: Both authors contributed equally to the conception and design of the study.

\section{REFERENCES}

Benson, S., \& DeKeyser, R. (2019). Effects of written corrective feedback and language aptitude on verb tense accuracy. Language Teaching Research, 23(6), 702-726.

Bijami, M., Pandian, A., \& Singh, M. K. M. (2016). The Relationship between teacher's written feedback and student's' writing performance: Sociocultural perspective. International Journal of Education and Literacy Studies, 4(1), 59-66.

Brown, H. (2000). Principles of language learning and teaching. Englewood Cliffs, N.J: Prentice-Hall.

Bui, T., \& Intaraprasert, C. (2013). The effects of attitude towards speaking English and exposure to oral communication in English on use of communication strategies by English majors in Vietnam. International Journal of Science and Research Publications, 3(2), 1-9.

Canceran, D.-J. B., \& Malenab-Temporal, C. (2018). Attitude of grade 12 SHS academic tracks students towards speaking in English. Journal of English as an International Language, 13(2.2), 219-231.

Chiang, K. M. K. (2004). An investigation into students' preferences for and responses to teacher feedback and its implications for writing teachers. Hong Kong Teachers' Centre Journal, 3, 98-115.

Cohen, A. D. (1991). Feedback on writing: The use of verbal report- Studies in second language acquisition. Cambridge: Cambridge University Press.

Cohen., L., Manion, L., \& Morrison, K. (2011). Research methods in education. New York: Routledge.

Corder, S. P. (1967). The significance of learner's errors. IRAL-International Review of Applied Linguistics in Language Teaching; $5(1-4), 161-170$

Davies, P., \& Pearse, E. (2002). Success in English teaching. Shanghai: Shanghai Foreign Language Education Press.

Diab, R. L. (2005). EFL university students' preferences for error correction and teacher feedback on writing. TESL Reporter, $38(1), 27-51$.

Djumingin, S., \& Weda, S. (2019). Anxiety in classroom presentation in teaching-learning interaction in English for students of indonesian study program at higher education. International Journal of Education and Practice, 7(1), 1-9. 
Dulay, H. C., \& Burt, M. K. (1974). Natural sequences in child second language acquisition 1. Language Learning, 24(1), 37-53. doi: https://doi.org/10.1111/j.1467-1770.1974.tbo0234.x

Eftekhar, M., \& Nouraey, P. (2013). Commercial translation error analysis: A case study of Iranian products. Linguistics and Literature Studies, 1(2), 55-60.

Eva, G., McMorrow, M., Molloy, R., \& Wilson, A. (2018). What kind of feedback helps students to improve their academic writing?

Ferris, D. R. (2006). Does error feedback help student writers? New evidence on the short- and long-term effects of written error correction. In K. Hyland \& F. Hyland (Eds.), Perspectives on response (pp. 81-98). Cambridge: Cambridge University Press.

Ferris., D. R. (2003). Response to student writing: Implications for second language students. Mahwah: Lawrence Erlbaum Associates.

Green, J. M., \& Oxford, R. (1995). A closer look at learning strategies, L2 proficiency, and gender. TESOL Quarterly, 29(2), 261297. doi: https://doi.org/10.2307/3587625

Guasti, M. T. (2017). Language acquisition: The growth of grammar. Cambridge, MA: MIT Press.

Hamouda, A. (2011). A study of students and teachers' preferences and attitudes towards correction of classroom written errors in Saudi EFL context. English Language Teaching, 4(3), 128-141. doi: https://doi.org/10.5539/elt.v4n3p128

Hibbert, L., \& Foncha, J. W. (2019). Improving student's performance in English as language of learning and teaching in teacher pre-service education. Journal of English as an International Language, 14(2), 29-43.

John, P., \& Woll, N. (2020). Using Grammar Checkers in an ESL Context: An Investigation of Automatic Corrective Feedback. Calico Journal, 37(2), 169-192.

Kern, R. (2000). Literacy and language teaching. Hong Kong: Oxford University Press.

Keshavarz, M. H. (1992). Contrastive analysis and error analysis: From theory to practice. Tehran: Rahnama Publication.

Kırkgöz, Y. (2010). An analysis of written errors of Turkish adult learners of English. Procedia-Social and Behavioral Sciences, 2(2), 4352-4358. doi: https://doi.org/10.1016/j.sbspro.2010.03.692

Kramsch, C., \& Widdowson, H. G. (1998). Language and culture. Oxford: Oxford University Press.

Lado, R. (1964). Language teaching: A scientific approach. New York: McGraw-Hill.

Lee, I. (2017). Teacher Feedback in L2 Writing Classroom Writing Assessment and Feedback in L2 School Contexts (pp. 65-82): Springer.

McDonough, J., Shaw, C., \& Masuhara, H. (2013). Materials and methods in ELT: A teacher's guide. Hoboken, NJ: John Wiley \& Sons.

Mikulski, A. M., Elola, I., Padial, A., \& Berry, G. M. (2019). Written feedback in heritage Spanish classrooms: A national survey of students and instructors. Revista Española de Lingüistica Aplicada/Spanish Journal of Applied Linguistics, 32(2), 543572 .

Mishchenko, O. (2019). Thematic magazines: Alternative method to control learning outcomes of future foreign language teachers. Journal of Education and e-Learning Research, 6(3), 116-121.

Nevo, B., \& Sfez, J. (1985). Examinees' feedback questionnaires. Assessment and Evaluation in Higher Education, 10(3), 236-248. doi: https://doi.org/10.1080/0260293850100305

Nouraey, P., Cuarteros, J. B., \& Khemiri, A. (2016). Omani students' written errors and improvements with special reference to paragraph writing: A cross-sectional study. International Journal of English Language and Translation Studies, 4(2), 120125.

Ranalli, J. (2018). Automated written corrective feedback: how well can students make use of it? Computer Assisted Language Learning, 31(7), 653-674.

Riazi, A., \& Riasati, M. (2007). Language learning style preferences: A students case study of Shiraz EFL institutes. Asian EFJ Journal, 9(1), 97-125.

Richards, J. C. (1974). Error analysis: Perspectives on second language acquisition. London: Longman. 
Sattayatham, A., \& Ratanapinyowong, P. (2008). Analysis of errors in paragraph writing in English by first year medical students from the four medical schools at Mahidol University. Silpakorn University International Journal, 8(3), 17-38.

Selinker, L. (1972). Interlanguage. IRAL-International Review of Applied Linguistics in Language Teaching, 10(1-4), $209-232$.

Yang, P.-L. (2019). Investigating the impact of English picture books on EFL learners'anxiety In Taiwan. Humanities and Social Sciences Letters, 7(2), 56-63. doi: https://doi.org/10.18488/journal.73.2019.72.56.63

Zhong, Q., Yan, M., \& Zou, F. (2019). The Effect of Teacher Feedback on the Simple Past Tense Acquisition in Senior High School Students' English Writing. World Journal of Education, 9(3), 30-37.

Views and opinions expressed in this article are the views and opinions of the author(s), International Journal of English Language and Literature Studies shall not be responsible or answerable for any loss, damage or liability etc. caused in relation to/arising out of the use of the content. 